\title{
Kim jest Gilbert Blythe? Portrety bohatera w powieści Ania z Zielonego Wzgórza Lucy Maud Montgomery i serialu Ania, nie Anna Moiry Walley-Beckett
}

Abstrakt:

Autorka artykułu podejmuje próbę scharakteryzowania i porównania dwóch kreacji - książkowej i serialowej - Gilberta Blythe’a. Pokazuje, że postać Gilberta w serialu Moiry Walley-Beckett (2017- ) pełni inną funkcję niż w powieści Lucy Maud Montgomery (1908). Gilbert jest nastolatkiem, uczniem szkoły w Avonlea, rywalem w nauce tytułowej bohaterki Ani z Zielonego Wzgórza. W powieści jego postać poznajemy wyłącznie przez pryzmat tego, co mówi i myśli o nim Ania Shirley - są to bardziej opinie niż fakty. W serialu Gilbert zostaje ukazany inaczej: twórcy poświęcają mu więcej czasu, rozbudowując jego postać oraz nadając mu nowe cechy. Relacja Ani i Gilberta staje się głębsza, bardziej realistyczna. W analizie porównawczej kreacji bohatera w obu tekstach kultury wykorzystano m.in. narzędzia z zakresu gender studies.

Słowa kluczowe:

adaptacja, Ania, nie Anna, Ania z Zielonego Wzgórza, dojrzewanie, gender, gender studies, Lucy Maud Montgomery, Moira Walley-Beckett, powieść dla dziewcząt, serial młodzieżowy

Who is Gilbert Blythe? The Portraits of the Character in Lucy Maud Montgomery's Novel Anne of Green Gables and Moira Walley-Beckett's TV Series Anne with an E

\section{Abstract:}

The author of the article attempts to characterise and compare two creations of Gilbert Blythe - the literary and the TV series ones. Apparently, Gilbert's character

* Karolina Starnawska - dr, pracuje w Katedrze Dydaktyki Języka i Literatury Polskiej na Wydziale Filologicznym Uniwersytetu Śląskiego. Jej zainteresowania badawcze obejmują literaturę dla młodego odbiorcy, dydaktykę literatury i nowe media w dydaktyce. Kontakt: karolina.jedrych@us.edu.pl. 
in Moira Walley-Beckett's TV series (2017-Present) has a different function than in Lucy Maud Montgomery's novel (1908). Gilbert is a teenager, a pupil at the Avonlea school, and a boy who competes at school with the titular character of Anne of Green Gables. In the book, we get to know him only through Anne Shirley's eyes - basing on what she says and thinks about him - and these insights are more opinions than facts. In the TV series, however, Gilbert is shown differently, as the creators of Anne with an E devote more screen time to developing this character and to bestowing him with new personality traits. Thanks to this, the relation between Anne and Gilbert becomes deeper and more realistic. The comparative analysis of the character's creations in both cultural texts is conducted with the use of, inter alia, the tools of gender studies.

\section{Key words:}

adaptation, Anne with an E, Anne of Green Gables, adolescence, gender, gender studies, Lucy Maud Montgomery, Moira Walley-Beckett, novel for girls, young adult TV series

\section{Wprowadzenie. Ania z Zielonego Wzgórza w Polsce}

$\mathbf{K}$ iedy w 1908 roku ukazała się Anne of Green Gables, polskim czytelnikom znana od 1911 roku jako Ania z Zielonego Wzgórza, jej autorka nie przypuszczała, że książka ta stanie się bestsellerem ani - tym bardziej - klasykiem literatury przeznaczonej dla młodszego czytelnika, szczególnie dziewczęcego. „Powieść dla dziewcząt” oraz „powieść dla dzieci” - do takich szufladek włożono bowiem debiutanckie dzieło kanadyjskiej autorki Lucy Maud Montgomery. Wypadałoby może uściślić, że pod takimi etykietami na pewno znajdziemy Anię... w Polsce, gdzie od kilku dziesięcioleci figuruje ona na listach lektur obowiązkowych lub uzupełniających ${ }^{1}$ dla uczniów szkół podstawowych z przedziału wiekowego 9-12 lat (klasy IV-VI) (Hoły, 2011, s. 88). Warto podkreślić, że nie taki był oryginalny adres czytelniczy powieści, która należała „do gatunku zwanego college girl literature, czyli do amerykańskiego i kanadyjskiego nurtu, którego odbiorczyniami były młode, kształcące się i emancypujące kobiety (w wieku ok. 16-20 lat)" (Oczko, Nastulczyk, Powieśnik, 2018, s. 264).

1 Warto dodać, że w najnowszej podstawie programowej do języka polskiego dla szkół podstawowych, obowiązującej od roku szkolnego 2017/2018, Ania z Zielonego Wzgórza znalazła się na liście dwudziestu dwóch lektur uzupełniających dla klas IV-VI. Wziąwszy pod uwagę, że nauczyciele muszą omówić z uczniami obowiązkowo tylko dwie lektury uzupełniające w ciągu roku, oraz fakt, że mogą wybierać także lektury spoza listy propozycji, jest możliwe, iż niektórzy uczniowie nie zetkną się z powieścią Montgomery w szkole. 
W polskich realiach Ania z Zielonego Wzgórza z powieści dla aspirujących do zdobycia wyższego wykształcenia dziewcząt stała się najpierw książką dla panienek, potem - dla dzieci. Ciekawy dowód recepcji powieści Montgomery daje zdanie Marii Kędziorzyny (1946) znalezione w recenzji Szkoły narzeczonych, debiutanckiej powieści Marii Krüger (1945). Omawiająca książkę na łamach Odrodzenia Kędziorzyna przytacza dialog zasłyszany jakoby w księgarni. Sprzedawca poleca kobiecie szukającej czegoś „dla dorastających panienek” właśnie Szkołę narzeczonych. Klientce nie podoba się ani tytuł, ani okładka przedstawiająca młodą dziewczynę z dzieckiem na ręku, ani „erotyczne zakończenie" (pierwszy niewinny pocałunek bohaterki z narzeczonym). Odrzuca egzemplarz Szkoły..., a następnie:

[...] wchodzi do antykwarni i kupuje Anię z Zielonego Wzgórza i tom drugi Anię $z$ Avonley [pisownia zgodna $\mathrm{z}$ oryginałem]. Wiadomo przynajmniej, co to jest. Książka moralna, przyzwoita, nadająca się dla panienek. Nic nie szkodzi, że egzemplarz brudny, wyświechtany, rozsypujący się. Ale za to treść czysta, zasady mocno postawione (Kędziorzyna, 1946, s. 12).

Cytat ten świadczy o tym, iż w polskim wydaniu powieści nie dopatrzono się żadnych treści szkodliwych, nowoczesnych czy wywrotowych dla panienek. I być może dlatego, po krótkim powojennym kryzysie nurtu tzw. powieści dla dziewcząt, Ania z Zielonego Wzgórza została wpisana na listę lektur polecanych do czytania w szkole.

Z uwagi na to, że główną bohaterką powieści jest dziewczynka, szkolne omawianie powieści skupia się zwykle właśnie na Ani i jej perypetiach ${ }^{2}$. Również polskie analizy i interpretacje powieści dotyczą raczej wykreowanego przez Montgomery świata dziewcząt oraz kobiet ${ }^{3}$. W tym szkicu chciałabym

2 Nawet autorzy interesującego raportu Męskość i kobiecość w lekturach szkolnych (Rient, Seklecka, Walczak, Walicka, Zierkiewicz, 2014, s. 36) piszą wyłącznie o Ani, pomijając postać Gilberta Blythe'a, a nawet Mateusza Cuthberta. Co ciekawe, autorzy opracowania powtarzają utarte opinie o Ani jako dziewczynce tracącej w toku akcji wiele interesujących cech - bohaterka z czynnej staje się bierna, rezygnuje z ambitnych planów na rzecz opiekowania się Marylą, którym to opiniom przeczą eseje napisane przez uczennice. Według nich Ania jest postacią dynamiczną, godną naśladowania, cenią jej dojrzałość oraz zdolność do zachowania wiary w człowieka, mimo traumy przeżytej w dzieciństwie.

3 Zaznaczmy, że w polskim literaturoznawstwie „naukowa refleksja nad odbiorem utworów Montgomery oraz ich recepcją dopiero się budzi” (Oczko, Nastulczyk, Powieśnik, 2018, s. 262). W literaturze przedmiotu znajdziemy o wiele więcej opracowań stricte metodycznych (scenariusze lekcji w czasopismach dla nauczycieli i tzw. książkach nauczyciela dołączanych do podręczników, publikacje w internecie itd.) niż naukowych. Nie zmienia 
skupić się na postaci szkolnego kolegi Ani Shirley - Gilberta Blythe’a, a dokładniej na porównaniu sposobów, w jakie bohater ten został wykreowany w powieści Ania $z$ Zielonego Wzgórza oraz w pierwszym sezonie serialu Anne with an E (polski tytuł to Ania, nie Anna) dystrybuowanego przez platformę Netflix $^{4}$, a będącego adaptacją pierwszej powieści Montgomery (Walley-Beckett, 2017- ) $)^{5}$.Zanim spróbuję odpowiedzieć na tytułowe pytanie („Kim jest Gilbert Blythe?”), dokonam krótkiego przeglądu współczesnych polskich interpretacji pierwszej powieści Montgomery.

\section{Polscy badacze o potrzebie feministycznej lektury Ani z Zielonego Wzgórza}

Ania z Zielonego Wzgórza była dotychczas tłumaczona z języka angielskiego na polski dwanaście razy (Wieczorkiewicz, 2017, s. 88), ale według danych zebranych przez Joannę Hoły (2011, s. 100) nadal najpopularniejszym przekładem na rodzimym rynku księgarskim pozostaje pierwszy, Rozalii Bernsteinowej (Montgomery, 1908/1911), którego język już od kilku lat określany jest jako „przestarzały” i „sentymentalny” (Kęczkowska, 2003). Te dwa fakty

to faktu, że „na tle dosyć nikłej światowej recepcji książek Montgomery, Polska stanowi przypadek zdecydowanie osobny i szczególny” (s. 262) - powieść kanadyjskiej autorki jest w ciągłym obiegu czytelniczym, wielokrotnie była tłumaczona i wznawiana.

4 Premiera pierwszego, siedmioodcinkowego sezonu Anne... w kanadyjskiej stacji telewizyjnej CBC odbyła się 19 marca 2017 roku. Na platformie Netflix serial pod tytułem Anne with an E ukazał się 12 maja 2017 roku. Drugi sezon liczy dziesięć odcinków i premierę miał 6 lipca 2018 roku. Za adaptację odpowiedzialna jest kanadyjska scenarzystka i producentka telewizyjna Moira Walley-Beckett. Jest pomysłodawczynią Anne with an E, napisała scenariusz do wszystkich odcinków sezonu pierwszego i trzech sezonu drugiego, jest też producentką wykonawczą serialu. Za reżyserię kolejnych odcinków odpowiedzialne były różne osoby: w sumie siedemnaście odcinków wyreżyserowanych było przez dziesięcioro twórców.

5 Dodajmy, że pierwszy sezon serialu początkowo sprawia wrażenie dość wiernej adaptacji powieści Ania $z$ Zielonego Wzgórza, wzbogaca on jednak jej treść o wątki psychologiczne - traumy Ani wywołane pobytem u sadystycznych opiekunów oraz w sierocińcu - a także kwestie emancypacyjne czy związane z dojrzewaniem i rozwojem fizycznym. Takich wątków w powieści napisanej na początku XX wieku nie ma, natomiast lektura pamiętników Lucy Maud Montgomery z lat jej młodości i do momentu wyjścia za mąż świadczy o tym, że pisarka była kobietą bardzo świadomą swojej cielesności (w różnych jej aspektach). Nie znaczy to jednak, że w jej osobistych dziennikach znajdziemy wprost wyrażone informacje o np. menstruacji czy współżyciu. Montgomery była dzieckiem swoich czasów i nawet w intymnych zapiskach posługiwała się językiem własnej epoki. 
- przestarzałe bądź nieudolne tłumaczenia oraz obecność na listach lektur szkolnych - stały się, zdaniem Piotra Oczki (2013), przyczyną wspomnianego wcześniej zaszufladkowania Ani..., „utrwalenia stereotypowego obrazu tytułowej bohaterki jako egzaltowanej dziewczynki, która ufarbowała sobie włosy na zielono” (s. 47-48). O samych przekładach badacz pisze nawet ostrzej: „[...] za sprawą niefortunnych wyborów tłumaczy (zarówno dawnych, jak i współczesnych) utwory Montgomery o Anne Shirley zostały w potocznej świadomości pogardliwie zdegradowane wyłącznie do roli naiwnej »literatury dla dorastających panienek«" (s. 45).

Podobne zdanie wyraziła kilka lat wcześniej Joanna Malicka (2008):

Współczesna recepcja twórczości pisarki jasno pokazuje, jak daleko w czytaniu serii o Ani odeszliśmy od zamierzenia autorki i jak ogromny wpływ na nasze dorosłe myślenie o tej książce ma wspomniana wcześniej banalizacja i infantylizacja wizerunku najsłynniejszej rudowłosej dziewczynki na świecie (s. 19).

Za „banalizacją i infantylizacją” stoi, zdaniem Malickiej, nieustanna obecność w szkole przekładu Bernsteinowej, brak powrotu czytelnika do powieści po latach (czyli brak lektury „dorosłej”, krytycznej, która potrafi wyjść poza odbiór dziecięcy, skupiający się głównie na zabawnych wydarzeniach z życia głównej bohaterki) oraz wpływ serialu (McDougall, Sullivan, 1985) z Megan Follows w tytułowej roli, będącego „bezrefleksyjnym przeniesieniem losów Ani na ekran telewizora" (Malicka, 2008, s. 21-22). Co ciekawe, zarówno Oczko (2013, s. 53-54), jak i Malicka (2008, s. 22) wysuwają w swoich tekstach postulat feministycznej lektury powieści Montgomery ${ }^{6}$. Ten typ czytania polegałby - co można wyczytać między wierszami artykułów - na poddaniu interpretacji postaw i wizerunków postaci kobiecych oraz poglądów bohaterek na temat np. edukacji dziewcząt, polityki, kościoła.

Tak właśnie analizuje Anię z Zielonego Wzgórza Iwona Gralewicz-Wolny (2013), wskazując możliwość feministycznego omawiania powieści Montgomery na lekcjach języka polskiego:

[...] ujęta w kontekst feministyczny, szkolna lektura Ani... mogłaby stać się skutecznym zaproszeniem chłopców do przeczytania tej, w końcu nie tak złej,

6 Na gruncie polskim takie propozycje są wciąż nowością, natomiast w anglojęzycznej literaturze znajdziemy wiele szkiców interpretacyjnych, w których proponuje się lekturę Ani... w duchu krytyki feministycznej. Zob. Åhmansson (1991), Ledwell, Mitchell (2013), Gammel, Epperly (1999), Gammel, Lefebvre (2010). 
powieści oraz sposobem na włączenie uczniów i uczennic w dyskurs płci, który toczy się tu i teraz... (s. 97).

Pełen tytuł artykułu Gralewicz-Wolny to: Ania z Zielonego Wzgórza - powieść dla „niegrzecznych" dziewcząt, przy czym ujęta w cudzysłów „niegrzeczność”, której badaczka nie definiuje wprost, byłaby zdolnością odbiorcy (czy raczej - odbiorczyni) powieści do wyłamywania się z narzuconej stereotypowej roli spokojnej, posłusznej, niewyróżniającej się niczym dziewczynki o łagodnym usposobieniu. Tutaj też - podobnie jak Malicka - Gralewicz-Wolny zderza postać rudowłosej Ani z Pippi Pończoszanką (Lindgren, 1945/2015), będącą w literaturze dziecięcej przykładem postaci aktywnej, nieokiełznanej, nieposłusznej, niedającej się ująć w ramy ról społecznych czy płciowych. Ania, podobnie jak czyni Pippi w odniesieniu do mieszkańców miasteczka, raz po raz szokuje obywateli Avonlea swoim zachowaniem, sposobem bycia i niecodziennymi działaniami. W przeciwieństwie do Pippi, bohaterka powieści Montgomery zyskuje pełną akceptację i realne wsparcie społeczności, w której odnajduje dom. Gralewicz-Wolny (2013, s. 94-95) podkreśla, że dziewczynkę wspierają przede wszystkim kobiety - Maryla Cuthbert i pani Lynde ${ }^{7}$, a także nauczycielka, panna Stacy. Do ich grona włączyłabym też ciotkę Józefinę Barry oraz pastorową Allan. Ania ma poza tym nieduże, lecz wierne grono szkolnych przyjaciółek - Dianę, Jankę i Ruby.

A co z powieściowymi chłopcami i mężczyznami? „It's a woman's world - to świat kobiecy, w którym mężczyźni są często przedstawiani w mało pochlebnym świetle", pisze Oczko (2013, s. 55), odnosząc się nie tylko do Ani $z$ Zielonego Wzgórza, lecz także do innych książek z cyklu ${ }^{8}$. Surowo ocenia portrety dorosłych mężczyzn kreślone przez autorkę, pisząc o nich jako o nieudacznikach, pantoflarzach, furiatach lub egoistach (s. 55). Gralewicz-Wolny (2013, s. 93) podkreśla jednak, że o pozostawieniu Ani na Zielonym Wzgórzu ostatecznie decyduje nie kto inny, jak wycofany i nieradzący sobie w kontaktach społecznych Mateusz Cuthbert. Istotnie: to on podejmuje decyzję, ma być dowodem na drugoplanową rolę społeczną kobiet w świecie przedstawionym powieści. Nie zgadzam się z taką interpretacją. To prawda, że Mateusz od początku przywiązuje się do Ani i skłonny jest - w przeciwieństwie do Maryli -

7 W takiej formie - zgodnie z oryginałem anglojęzycznym - pozostawia w swoim przekładzie to nazwisko Paweł Beręsewicz. Czytelnik polski przyzwyczajony jest co prawda do formy „Linde”, niemniej w tłumaczeniu, z którego pochodzą cytaty użyte w tym szkicu, zachowano postać nazwiska „Lynde”.

8 Jeśli liczyć dwa tomy opowiadań o Avonlea, na cykl składa się w sumie jedenaście tomów. 
zatrzymać ją na Zielonym Wzgórzu. Faktem jest, że jego surowa i dominująca siostra zasłania się nim, kiedy widzi, w jakich warunkach zamieszkałaby Ania, gdyby Cuthbertowie nie pozwolili jej zostać na swojej farmie. Zasłania się jednak bratem nie dlatego, że czuje się od niego słabsza czy boi się samodzielnie rozstrzygać o losie dziewczynki, ale ponieważ nie do końca jest przekonana o tym, czy powinna ją oddać pani Blewett. Zanim Maryla powie: „Chyba lepiej zabiorę ją z powrotem do domu i jeszcze to omówimy z Mateuszem. Nie bardzo mogę podjąć decyzję bez porozumienia z nim" (Montgomery, 1908/2014, s. 60), poczuje, patrząc na zrozpaczoną Anię, „[...] że jeśli nie odpowie na to wołanie bez słów, do końca życia nie zazna spokoju” (s. 60). To sumienie nie pozwoliło Maryli na oddanie Ani, a nie Mateusz. Pozostajemy zatem mimo wszystko w świecie kobiet i dziewcząt, rzecz jasna ograniczonych pewnymi normami, czy to obyczajowymi, czy to prawnymi, lecz (jak na czas, w którym rozgrywa się ta historia - koniec XIX wieku) silnych, niezależnych, chcących realizować się zarówno w rolach żon, matek, gospodyń domowych, opiekunek, jak również przyjaciółek, prymusek, studentek, nauczycielek.

W tym świecie, świecie kobiet w różnym wieku i dorastających dziewcząt, łatwo stracić z oczu postacie chłopców i mężczyzn, zwłaszcza że w pierwszej powieści z cyklu o Ani w zasadzie tymi odgrywającymi większą pod względem fabularnym rolę są jedynie wspominany już Mateusz, pan Philips (nauczyciel w Avonlea) oraz Gilbert, szkolny kolega Ani i jej „dobry wróg” (Montgomery, 2014, s. 365). Lektura feministyczna Ani z Zielonego Wzgórza, której podejmują się Malicka, Oczko i Gralewicz-Wolny, eksponuje bohaterki, ich czyny, myśli, słowa, ich „niegrzeczność". Gdybym nie widziała serialu Anne with an E, taka lektura stałaby się też moim udziałem, gdyż na polskim gruncie feministyczne czytanie klasyki dziecięcej i młodzieżowej wciąż jest jeszcze nowością. Produkcja dystrybuowana przez Netflix, na którą - jak do tej pory (lipiec 2019) - składa się siedemnaście odcinków podzielonych na dwa sezony, otwiera pole zarówno dla interpretacji feministycznych, jak i, szerzej, genderowych. Zachęca do ponownego odczytywania i reinterpretowania tych, wydawałoby się, dobrze znanych postaci Ani, Maryli czy pani Lynde oraz do przyjrzenia się bliżej owym powieściowym, powtórzmy, „pantoflarzom”, „nieudacznikom”, „furiatom" (Oczko, 2013, s. 55).

Na pierwszy rzut oka, czyli po jednokrotnym obejrzeniu pierwszego sezonu serialu Anne with an E, mogłoby się wydawać, że adaptacja Moiry Walley-Beckett koncentruje się jedynie na postaciach żeńskich. Bohaterki, które w powieści i tak są dość wyraziste, tutaj zyskują cechy, które były zawarte między wierszami Ani z Zielonego Wzgórza, bądź zupełnie nowe, jakby nadpisane przez scenarzystkę, przez co serialowe portrety kobiet i dziewcząt stają 
się momentami przejaskrawione, a widzowi zbyt często bardzo dosadnie podaje się informację, że dziewczynki mogą robić to samo, co chłopcy (Walley-Beckett, Caro, 2017), być bohaterkami własnej historii i nie wychodzić za mąż (Walley-Beckett, Fox, 2017). Oczywiście, że mogą, ale - z punktu widzenia sztuki filmowej - powtarzanie takich stwierdzeń kilka razy na odcinek wydaje się konstrukcyjną nieporadnością. To samo można by wyrazić inaczej, nie wprost, pokazując np. jak bohaterowie zachowują się w konkretnych sytuacjach, jakie są ich motywacje, a jakie dylematy, które emocje kierują ich działaniami. I tak właśnie zostali przedstawieni w adaptacji z 2017 roku chłopcy i mężczyźni z Avonlea. W Anne with an E, która w polskich serwisach internetowych publikujących recenzje czy omówienia serialu często występuje z przymiotnikiem "feministyczna", Walley-Beckett nie skupia się wyłącznie na świecie kobiet. Pokazuje widzowi także chłopców i mężczyzn, którzy muszą zmagać się z wyzwaniami codzienności oraz borykać z przerastającymi ich problemami. Szczególną uwagę twórcy serialu zwracają na postacie Mateusza Cuthberta (R. H. Thomson) i Gilberta Blythe'a (Lucas Jade Zumann), choć i pan Philips (Stephen Tracey) ma tu interesujące cechy. Sportretowani są też szkolni koledzy Ani jako grupa antagonistyczna względem dziewczynek. Nowe, przerażające oblicze zyskał np. Billy Andrews (Christian Martyn), brat Jane (w polskim przekładzie Bernsteinowej - Janki; w tej roli Lia Pappas-Kemps). Bohaterom tym w książce nie poświęca się wiele miejsca, bo sama powieściowa Ania nie zwraca na nich większej uwagi, żyjąc w świecie dziewczęcych marzeń, do których nie wkrada się jeszcze żaden kandydat na sympatię lub towarzysza życia.

Jedynym chłopcem, któremu Ania Shirley poświęca czas, choć wypadałoby raczej powiedzieć, że usilnie stara się nie poświęcać mu nawet wzmianki w swoich opowieściach o szkolnym życiu, jest jej kolega Gilbert Blythe. Choć w serialu Anne with an E nie przeznaczono dla niego tyle samo czasu ekranowego co dla tytułowej protagonistki (zagranej przez Amybeth McNulty), to trudno zdecydowanie określić go jako bohatera drugoplanowego. Jego historia

9 Po lekturze artykułów prasowych, recenzji i komentarzy można odnieść wrażenie, że przymiotnik „feministyczny” jest w związku z serialem używany w wielu przypadkach bezrefleksyjnie, w znaczeniu potocznym - skoro opowiadana historia eksponuje losy dziewcząt, a przy tym mówi się w niej o menstruacji oraz prokreacji, to na pewno oznacza „feminizm”. To duże uproszczenie. Nawet stwierdzenie, że serial jest reinterpretacją feministyczną powieści, w mojej opinii nie jest wystarczające. Produkcja wpisuje powieść w dyskurs feministyczny początku XXI wieku - i to w konkretną gałąź tego dyskursu, związaną z m.in. teorią queer, ekofeminizmem i postkolonializmem. To zagadnienie stanowi już materiał na inny tekst, w którym analizie trzeba by poddać oba sezony programu. 
w pewnym momencie zaczyna być na tyle interesująca, że twórcy serialu w kolejnej odsłonie programu wątek Gilberta czynią drugim głównym wątkiem fabularnym. Nie podejmę się tutaj interpretacji postaci Gilberta w sezonie drugim, w którym chłopak opuszcza rodzinne Avonlea i zderza się z kwestiami leżącymi jak do tej pory poza horyzontem znanego mu świata. Chcąc przejść do rozważań o serialowym młodym Blycie, muszę jednak przedstawić jego wizerunek książkowy. Wobec krytyki, z jaką spotyka się wśród współczesnych badaczy najstarszy z przekładów Ani z Zielonego Wzgórza, na potrzeby tego szkicu sięgnęłam po przekład Pawła Beręsewicza (Montgomery, 1908/2014), który bardziej niż przekład Agnieszki Kuc (Montgomery, 1908/2003) uwspółcześnił język zarówno narratora, jak i mieszkańców Avonlea.

\section{Gilbert powieściowy}

Narracja Ani z Zielonego Wzgórza jest trzecioosobowa, najczęściej prowadzona z punktu widzenia Ani Shirley, choć początkowe rozdziały, zgodnie z ich tytułami, skupiają się na tym, co widzieli pani Rachel Lynde, Mateusz i Maryla Cuthbertowie. W dalszej części opowieści narrator również pozwala nam od czasu do czasu śledzić wydarzenia z perspektywy tych bohaterów, choć oczywiście to Ania, jej przemyślenia, emocje i czyny są w centrum jego uwagi. Nie ma natomiast $\mathrm{w}$ utworze takiej sytuacji, w której czytelnik mógłby bardziej zapoznać się z tym, co myśli i czuje Gilbert Blythe. Informacje o tym są raczej zdawkowe, a o bohaterze wiemy tylko tyle, ile skłonna jest powiedzieć - lub pomyśleć - sama Ania. Dziewczyna, od czasu niefortunnego wydarzenia z tabliczką (o czym piszę dalej), bardzo stara się, by chłopak nie zaprzątał jej głowy; przez lata nie wymawia nawet jego imienia w całości.

Pierwszy raz o Gilbercie słyszymy od przyjaciółki Ani od serca - Diany Barry:

Jest strasznie przystojny, Aniu. I okropnie dokucza dziewczynkom. Po prostu nie daje nam spokoju!

Ton Diany wskazywał, że to niedawanie spokoju zbytnio jej nie martwiło (Montgomery, 1908/2014, s. 131).

Zwróćmy uwagę na to, co Diana uznaje za najważniejsze w swoim koledze: wygląd i niezupełnie zgodny z normami grzeczności sposób odnoszenia się do koleżanek. $\mathrm{Z}$ tonu dziewczynki wynika, że taka postawa chłopaka jest akceptowana. Czy to dlatego, że wyróżnia się on urodą? Czy dziewczętom pochlebia 
zainteresowanie ze strony ładnego chłopca, objawiające się tym niedookreślonym „dokuczaniem”? Być może. W rozmowie okazuje się, że Gilbert ma jeszcze jedną cechę, którą nie wiadomo, czy zakwalifikować do pozytywnych czy negatywnych - lubi być najlepszy, co może zagrozić pierwszemu miejscu Ani w klasie. Dziewczynka akurat cieszy się z tego, że będzie mogła rywalizować z kimś równym sobie. Kiedy Ania po raz pierwszy idzie do szkoły, ma około jedenastu i pół roku. W przeciwieństwie do rówieśniczek, które „są już w piątej książce", ona, z powodu dotychczasowych zaniedbań w edukacji, przerabia materiał z czwartej (Montgomery, 1908/2014, s. 130). Podobnie czternastoletni Gilbert, który z powodu choroby ojca przebywał w odległej Albercie i przez trzy lata „prawie w ogóle nie chodził do szkoły” (s. 132).

Zauważmy, że za sprawą słów Diany w Ani może już kształtować się obraz Gilberta jako dobrze wyglądającego, złośliwego i do tego przemądrzałego chłopca. Dumna i bardzo ambitna Ania na podstawie kilku informacji ma sposobność nastawić się negatywnie do nieznanego kolegi. Narrator co prawda nie sugeruje takiej interpretacji, ale też nie daje ani głównej bohaterce, ani czytelnikowi szansy na to, by w scenie, kiedy w końcu bohaterka widzi Gilberta, dostrzegł w chłopaku postać, do której można zapałać sympatią. Zachęcona przez Dianę Ania zerka na kolegę akurat w momencie, gdy ten dokucza jednej z dziewcząt. Po całej psocie mruga do Ani „niezwykle zadowolony z żartu” (Montgomery, 1908/2014, s. 133). Dziewczynka przyznaje Dianie, że jest on przystojny, ale też bezczelny - i to bynajmniej nie dlatego, że dokucza koleżankom, ale z uwagi na to, że mruga do nieznajomych.

Tymczasem Ania intryguje Gilberta zupełnym ignorowaniem go. Chłopak „nie przywykł do tego, żeby jakakolwiek dziewczyna zbywała wezwanie do zwrócenia na niego uwagi" (Montgomery, 1908/2014, s. 134). To właśnie z tego powodu postanawia uciec się do najgorszego możliwego sposobu przełamania obojętności Ani - przezywa ją „marchewką”. Dziewczynka, szczególnie wrażliwa na punkcie koloru swoich włosów oraz wyrwana ze świata snutych na lekcji marzeń, wpada w gniew i rozbija Gilbertowi na głowie tabliczkę. Za takie zachowanie zostaje ukarana przez nauczyciela, mimo iż Gilbert staje w jej obronie, przyznając się do prowokacji. Stojąc pod tablicą z napisem: „Ann Shirley ma bardzo zły charakter. Ann Shirley musi się nauczyć panować nad złością”, dziewczynka podejmuje decyzję: „Nie zamierzała już nigdy na niego spojrzeć. Postanowiła, że w życiu się do niego nie odezwie" (s. 136). I trwa w gniewie, mimo niemal natychmiastowych przeprosin ze strony skruszonego Gilberta oraz mimo pojednawczych zabiegów Diany, która tak tłumaczy chłopca: „No przecież on się nabija ze wszystkich dziewczynek. [...] I jeszcze nigdy nie słyszałam, żeby za cokolwiek przeprosił. Nigdy" (s. 137). 
Gniew Ani przybiera na sile, kiedy kolejnego dnia zostaje za karę posadzona w jednej ławce z Gilbertem. „Jak w wielkim kotle wrzały w niej złość, wstyd i upokorzenie" - pisze autorka (Montgomery, 1908/2014, s. 139). Różowy cukierek w kształcie serca, który $\mathrm{Gil}^{10}$ na zgodę podsuwa dziewczynce, zostaje demonstracyjne przez nią rozdeptany. Po tym incydencie Ania postanawia porzucić szkołę. Uczy się w domu, spotyka z Dianą, a napotkanego we wsi Gilberta ignoruje i mija „z pogardliwą obojętnością, nie zwracając najmniejszej uwagi na jego wyraźną chęć pojednania" (s. 143). Kiedy w końcu wraca do szkolnej ławy, jabłko zgody, ofiarowane przez Gilberta, spotyka się z taką samą wzgardą, jak ofiarodawca. Tutaj rozpoczyna się, trwająca do ukończenia studiów w Queen's Academy ${ }^{11}$, rywalizacja Ani i Gilberta w nauce. W ciągu kolejnych lat Gilbert Blythe, a raczej wyobrażenie Ani o nim, pełni dla bohaterki funkcję trampoliny, od której dziewczyna odbija się, by ciągle udowadniać sobie samej i innym, że nie tyle jest najlepsza ze wszystkich, ile przede wszystkim lepsza od niego:

Ania rzuciła się w wir nauki, żeby za żadne skarby nie dać się wyprzedzić Gilbertowi Blythe’owi. [...] Gilbertem powodował po prostu zdrowy duch współzawodnictwa, czego niestety chyba nie dało się powiedzieć o Ani, która miała niezbyt chwalebną skłonność do pielęgnowania urazy. [...] Oczywiście nigdy by się nie przyznała, że zależy jej na wyprzedzeniu Gilberta w nauce. To by oznaczało uznanie jego istnienia, czego Ania cały czas uparcie odmawiała. [...] W pierwszym miesiącu [egzaminów] Gilbert wyprzedził Anię o trzy punkty. W drugim Ania pokonała go o pięć. Triumf byłby całkowity, gdyby nie to, że Gilbert publicznie przed całą klasą pogratulował jej zwycięstwa, które smakowałoby o wiele słodziej, gdyby sprawiło pokonanemu ból (Montgomery, 1908/2014, s. 165).

Krytyczne przyjrzenie się tej relacji ujawnia negatywne cechy głównej bohaterki, którą zwykliśmy uważać za dziewczynę bujającą w obłokach, rozgadaną, wesołą, tymczasem Ania bywa zawzięta, dumna i uprzedzona do Gilberta. Nie przebacza mu nawet wtedy, gdy chłopak ratuje ją przed utonięciem w trakcie inscenizacji Lancelota $i$ Elaine Alfreda Tennysona (1859/1902). Kiedy Ania odrzuca kolejną prośbę Gilberta o przebaczenie, chłopak postanawia traktować ją jak powietrze. Ona tymczasem szybko przekonuje się, „że nie jest miło być

10 Takiego skrótu imienia bohatera używa w swoim przekładzie, w zgodzie z oryginałem, Paweł Beręsewicz.

11 Czyli około pięciu lat. Pod koniec powieści Ania ma szesnaście i pół roku (Montgomery, 1908/2014, s. 360). 
ignorowaną" (Montgomery, 1908/2014, s. 291). Dochodzi też do wniosku, iż „zupełnie nie wiedząc kiedy, wybaczyła [Gilbertowi] i zapomniała [dawne, negatywne emocje, jakie do niego żywiła]" (s. 291). Mimo tego nie potrafi wyciągnąć ręki na zgodę.

Podczas egzaminów próbnych Gilbert staje się bohaterem koszmarów Ani, natomiast podczas tych oficjalnych ponownie motywuje dziewczynę do bycia najlepszą. Tym razem jednak to nie gniew na Gilberta nią kieruje, a żal do siebie samej: „Za każdym razem, gdy Ania podnosiła głowę odrobinę wyżej, odrobinę bardziej żałowała, że nie pogodziła się z Gilbertem, kiedy ją o to prosił, i odrobinę solenniej obiecywała sobie, że prześcignie go na egzaminie" (Montgomery, 1908/2014, s. 309). Widzimy, jak bardzo dziewczyna nie chce przyznać się przed chłopakiem do błędu i jak przekuwa swój żal na ambicję. $Z$ jeszcze dziwniejszą sytuacją mamy do czynienia podczas koncertu, na którym Ania występuje z recytacją. Bohaterka, nie mogąc z przerażenia zacząć występu, dostrzegłszy Gilberta na widowni, jest przekonana, że chłopak uśmiecha się do niej złośliwe, i to przekonanie daje jej siłę, by odzyskać panowanie nad sobą. W rzeczywistości Gil uśmiechał się, bo podobał mu się koncert.

O Gilbercie nie wiemy więc wiele: jest przystojny, ambitny, dobrze się uczy, potrafi przyznać się do błędu, ma swoją dumę, która nie pozwala mu prosić dwa razy o przebaczenie. Podobnie jak Ania, jest też zawzięty - kiedy postanawia ignorować „marchewkę”, to czyni to konsekwentnie dopóty, dopóki Ania pierwsza nie przemówi do niego. Nie jestem pewna, czy możemy ufać nawet tej pozytywnej opinii, podsumowującej przemyślenia Ani o tym, że Blythe mógłby być jej dobrym przyjacielem: „Gilbert był mądrym, samodzielnie myślącym młodzieńcem, wiedział, czego chce, i zamierzał przeżyć życie najpełniej, jak potrafi" (Montgomery, 1908/2014, s. 334). Na obraz tego bohatera składają się nieliczne fakty oraz liczniejsze opinie i wyobrażenia Ani Shirley o nim. Gilbert istnieje jako postać, bo istnieje Ania. W powieści dla dziewcząt protagonistka zawsze ma swojego adoratora lub kogoś, do kogo wzdycha z miłości. Ania - niczym Elizabeth Bennet z Dumy i uprzedzenia (Austen, 1813/2016) - zamiast obiektu uwielbienia ma obiekt niechęci, która stopniowo przeradza się w zainteresowanie. Ostatecznie obie bohaterki do mężczyzny ich życia przekonują szlachetne i bezinteresowne czyny, nie słowa. Pan Darcy ratuje przed zniesławieniem siostrę Elizabeth, a Gilbert oddaje Ani swoją posadę w szkole w Avonlea. Dziewczyna zdobywa się na to, by mu podziękować, a on proponuje jej zgodę oraz przyjaźń. I na tym kończy się historia tych dwojga opisana w Ani z Zielonego Wzgórza. 


\section{Gilbert serialowy}

Dzieje Gilberta serialowego mają bardzo podobny początek co losy Gilberta książkowego. Pierwszego dnia Ani w szkole Diana, odgrywająca rolę przewodniczki przyjaciółki, podaje jej informację, która okaże się kluczowa dla funkcjonowania w tej społeczności: „Nie rozmawiaj z chłopcami. Są śmieszni. Wszyscy z wyjątkiem Gilberta Blythe'a. Jest wspaniały [He is dreamy, czyli - jest jak marzenie!]" (Walley-Beckett, Goldbacher, 2017). Okazuje się, że w serialowym Avonlea istnieją jeszcze inne niepisane zasady dotyczące kontaktów z chłopcami: „Nie daj im poznać, że sprawili ci przykrość. Ani że ich lubisz" (Walley-Beckett, Goldbacher, 2017). Podział na świat dziewcząt i chłopców widoczny jest w organizacji przestrzeni sali szkolnej - dziewczęta siedzą w ławkach po prawej stronie nauczyciela, chłopcy po lewej, a między tymi rzędami jest bardzo szerokie przejście. Ania wie zatem, że Gilbert jest wspaniały - nie wie jednak, pod jakim względem. Chodzi o wygląd czy o zachowanie? A może o przymioty umysłu? Nie pada tutaj informacja o tym, że dokucza dziewczętom, bo tak się składa, że serialowy Gilbert będzie daleki od bycia złośliwym w stosunku do koleżanek. Zamiast pewnego siebie szkolnego "przystojniaka” twórcy serialu Anne with an E postanowili dać widzom „rycerza”.

Gilberta poznajemy w trzecim odcinku pierwszego sezonu, tym samym, w którym Diana mówi o nim, że jest dreamy. Idącą przez las Anię zaskakuje - dokuczający jej już pierwszego dnia szkoły - Billy Andrews. Billy to typowy przykład chłopaka, który dręczy słabszych. W języku angielskim taką osobę określa się mianem bully, a to, co robi, to bullying, czyli znęcanie się - słowne, psychiczne, fizyczne - nad słabszymi uczniami. Słabością dziewczyny w oczach Billy’ego oraz osób pokroju tego chłopca jest jej sieroctwo, które od początku znajomości z Anią Billy agresywnie komentuje. W lesie samotna Ania narażona jest nie tylko na słowne, lecz także fizyczne zaczepki ze strony Andrewsa. Kiedy sytuacja staje się niebezpieczna, wkracza Gilbert. Samo jego pojawienie się sprawia, że Billy zostawia Anię w spokoju. Dziewczyna jest tak przestraszona, że nawiązuje tylko minimalny kontakt ze swoim wybawcą, który już do jej pleców woła: „Potrzebujesz ubić jeszcze jakiegoś smoka?” (Walley-Beckett, Goldbacher, 2017). W tej scenie twórcy serialu nie grają $\mathrm{z}$ widzem w subtelne skojarzenia: Anię obsadzają w roli damy w opresji, Billy'ego w roli potwora, a młodego Blythe'a - rycerza. Taka charakterystyka Gilberta zostanie potwierdzona w kolejnym odcinku. Kiedy podczas remontu domu Gillisów Billy znów wyśmiewa dziewczęta, Blythe pomaga im, swoją postawą (i słowami!) pokazując, że jest zupełnie innym typem chłopaka niż Andrews. Zauroczona kolegą 
Ruby (Kyla Matthews) mówi: „Gilbert jest taki rycerski [chivalrous, a więc także szarmancki]” (Walley-Beckett, Evans, 2017).

Tym, co łączy serialowego i książkowego Gilberta, jest fakt, że od początku w obu swoich kreacjach interesował się Anią. Nie dlatego, że ta nie zwracała na niego uwagi, z czym do tej pory nie zetknął się w przypadku żadnej dziewczynki. Powoduje nim raczej zwyczajna ciekawość - kim jest ta dziewczyna, której pomogłem? Gilbert biegnie za Anią całą drogę do szkoły, próbując dowiedzieć się, jak ma na imię. W uprzejmym geście, którego nie powtarza żaden z jego szkolnych kolegów ani w tym, ani w kolejnych odcinkach, otwiera przed nią drzwi szkoły i wpuszcza pierwszą. Dopiero wtedy Ania decyduje się do niego odezwać, przepraszając za to, że była nieuprzejma (Walley-Beckett, Goldbacher, 2017). Dzieje się jednak coś ciekawego po pierwsze, Gilbert zostaje entuzjastycznie przywitany przez kolegów, a po drugie, koleżanki Ani patrzą na nią z wyraźnym zdziwieniem, niewróżącym niczego dobrego. Jak się za chwilę okaże, Gil jest już „zaklepany” przez jedną z dziewcząt, Ruby Gillis, która kocha się w nim od trzech lat. Aby nie naruszać delikatnej równowagi w gronie dorastających dziewcząt, Ani nie wolno wchodzić w jakiekolwiek interakcje z Gilbertem - rozmawiać z nim, patrzeć na niego. Okazuje się, że była o krok od zranienia uczuć Ruby. Chcąc pozostać w łaskach koleżanek, Ania musi unikać jedynego chłopca w szkole, który okazał jej odrobinę sympatii.

Przed sceną z dziewczynkami mamy tę prezentującą Gilberta z kolegami. „Dlaczego szedłeś z tą sierotą? [...] To wariatka. [...] Obyś nie dostał wszy z sierocińca” - mówi jeden z nich. Gil ze spokojem odpowiada: „Czemu nie? [...] Poza tym, nie dbam skąd jest. Ważne, że ładna" [A cute girl is a cute girl] (Walley-Beckett, Goldbacher, 2017). Ewentualna bliższa znajomość Ani i Gilberta nie będzie więc dobrze widziana ani przez dziewczynki, ani przez chłopców. Jednocześnie Gil zostaje nam pokazany jako chłopak odstający od reszty klasy - właśnie wrócił z dalekiej Alberty (w książce wracał „tylko” od kuzynów w Nowym Brunszwiku, w Albercie był wcześniej), jego ojciec choruje (jeszcze nie wiemy, na co i jak poważnie). Gilbert wreszcie jako jedyny nie naśmiewa się z Ani z powodu jej pochodzenia. Co więcej, znajduje na jej określenie przymiotnik o nacechowaniu pozytywnym. Podobnie jest podczas lekcji - cała klasa przewraca oczami i śmieje się cicho z czytającej na głos z wielkim zaangażowaniem, a nawet egzaltacją, Ani, a Gilbert szepce do kolegi: „Dobra jest. Wczuwa się" (Walley-Beckett, Goldbacher, 2017). On i Diana są jedynymi uczniami, którzy nie wybuchają śmiechem, kiedy lektura dobiega końca. Chłopak podczas przerwy próbuje nawiązać kontakt z Anią, proponując jej jabłko. Wszystkiemu jednak przyglądają się koleżanki bohaterki. To prawdziwa próba 
- chcąc należeć do dziewczęcego kręgu, Ania musi odrzucić w sposób zdecydowany nierozumiejącego jej sytuacji chłopaka. „Nie wolno mi z tobą rozmawiać" - krzyczy. Gilbert pyta, dlaczego, ale nie otrzymuje odpowiedzi (Walley-Beckett, Goldbacher, 2017).

Bohater jest bardzo wytrwały i podejmie jeszcze trzecią próbę dotarcia do Ani. Twórcy serialu nie przedstawili go jako odrzuconego adoratora, który musi udowodnić, że zainteresuje się nim każda dziewczynka. Gilbert jest spokojny, bardzo opanowany i dociekliwy. Wydaje się, że zwyczajnie chciałby wiedzieć, kim jest ta uparta dziewczyna, która najwyraźniej zaintrygowała go swoim zachowaniem. W zasadzie do tego Gilberta nie pasuje pociągnięcie Ani za warkocz i nazwanie jej „marchewką”, ale rezygnacja z tej kluczowej dla relacji Shirley - Blythe sceny nawet w serialu, który tak swobodnie interpretuje pierwowzór powieściowy, byłaby chyba zbyt mocnym odejściem od utworu Montgomery. Scenę więc pozostawiono, ale zmieniono jej znaczenie. Gilbert podczas lekcji najpierw rzuca w Anię papierkami, usiłując zwrócić jej uwagę, a potem przekracza granicę między częścią chłopięcą a dziewczęcą klasy i ponownie próbuje wręczyć protagonistce jabłko. Widać, że dziewczyna nie ma ochoty na niego spojrzeć, stresuje ją ta sytuacja. Jak długo może, nie zwraca uwagi na chłopaka. Zza jej pleców wszystkiemu przygląda się zakochana w Gilbercie Ruby. Jeśli Ania przyjmie „zaloty” chłopca, zostanie odrzucona przez koleżanki, a przecież w serialowej opowieści nie zostaje od razu zaakceptowana przez klasę, jak ma to miejsce w książce. Spoliczkowanie Gilberta tabliczką (nie zaś rozbicie tabliczki na jego głowie) z okrzykiem: „Nie rozmawiam z tobą!” (Walley-Beckett, Goldbacher, 2017) to rozpaczliwa próba obrony siebie samej. Pod tym gestem i słowami kryje się komunikat: „Zostaw mnie, chcę zadomowić się w tym świecie, nie ułatwiasz mi tego". Ukarana przez pana Philipsa, upokorzona Ania wychodzi ze szkoły, by nie pojawić się w niej przez kilka kolejnych tygodni. Gdy w końcu decyduje się powrócić, zostaje entuzjastycznie przywitana przez koleżanki, a Gilbert uśmiecha się delikatnie do siebie, jakby też cieszył go taki obrót spraw (Walley-Beckett, Evans, 2017).

Przełomowy dla wątku Gilberta staje się odcinek piąty (Walley-Beckett, Rozema, 2017). Jest to słynny epizod, w którym Ania pierwszy raz miesiączkuje, a twórcy podejmują zagadnienia dorosłości, dojrzewania, granicy między byciem dziewczyną a byciem kobietą. Waga tego tematu sprawia, że losy Gilberta schodzą na dalszy plan, chociaż powoli pokazywane jest jego wkraczanie w dorosłe życie. Nieprzypadkowo twórcy serialu przedstawiają go jako chłopaka innego od reszty kolegów z klasy. Na początku odcinka widzimy, że zajmuje się czynnością przypisaną tradycyjnie kobietom - przygotowuje śniadanie dla siebie i kogoś jeszcze. Możemy domyślać się, że dla ojca, ponieważ była już 
o nim mowa; o matce - nie. Zresztą, gdyby matka chłopaka żyła, zapewne to ona przygotowywałaby posiłek. Hipoteza o jej śmierci zostaje potwierdzona dopiero w odcinku szóstym, tymczasem jedyną kobietą na farmie Blythe’ów bywa gosposia. Jest w tym odcinku jeszcze jedna scena, w której Gilbert przygotowuje coś dla ojca. Zmontowana została symultanicznie ze sceną przedstawiającą Anię szykującą swój pierwszy dorosły podwieczorek, na który Maryla pozwoliła jej zaprosić Dianę. Herbatka, w książce zakończona upiciem przyjaciółki Ani, $\mathrm{w}$ serialu jest wyprawiana $\mathrm{z}$ okazji pierwszej menstruacji i przez przypadek obie dziewczynki odurzają się winem Maryli. W tym czasie Gilbert nalewa ojcu herbatę i czyta jego ulubiony wiersz, rozpoczynający się od słów: „Pieszo i z lekkim sercem udaję się w drogę / Zdrowy, wolny, droga przede mną". To fragment Poem of the Road Walta Whitmana (1856), stanowiący w przypadku Johna Blythe'a (David Fox) zapowiedź jego śmierci (Walley-Beckett, Rozema, 2017).

O ile Ania chętnie i ze szczegółami dzieli się z koleżankami tym, że dostała okres, o tyle nie widzimy, by Gilbert opowiadał kolegom o swoim życiu prywatnym, domowym. W zasadzie w ogóle brak scen, w których chłopcy rozmawialiby ze sobą na jakiś konkretny temat. Podczas gdy dziewczynki na przerwie opowiadają sobie, jak u nich wygląda czas menstruacji, ich koledzy oddają się dość bezmyślnie wyglądającej zabawie w bezładne uderzanie pieńka kijami (Walley-Beckett, Rozema, 2017). Istnieje wspólnota dziewczynek, w której mogą one podzielić się ze sobą tajemnicami, niepokojami czy rozterkami, lecz nie ma analogicznej wspólnoty chłopców. Gilberta portretuje się jako innego i odosobnionego nie tylko dlatego, że od początku ma pozytywne zdanie na temat Ani, lecz także dlatego, że nie oddaje się podwórkowym chłopięcym rozrywkom i dobrze się uczy. Gil jako jedyny chłopak był poza Avonlea, widział wielki świat. Poza tym tylko on jako nastolatek musi zajmować się chorym ojcem, o czym zagniewana Ania przekonuje się naocznie, kiedy na polecenie nauczyciela przekazuje Gilbertowi materiał z opuszczonych przez chłopaka lekcji. Tak, w serialu Ania odzywa się do Gilberta, aczkolwiek czyni to nie z własnej woli i raczej niechętnie. Nie ma tu jednak wątku trwającej pięć lat wrogości.

Twórcy serialu zdecydowali się na postawienie chłopaka w sytuacji, w której musi stać się bardziej odpowiedzialny niż rówieśnicy, co staje się wyznacznikiem jego dojrzewania. Ta odpowiedzialność wiąże się z samotnością. W odcinku piątym (Walley-Beckett, Rozema, 2017) Gilbert ma jedną wspólną i do tego krótką scenę z ojcem - tę już wspominaną, prezentującą czytanie wiersza. Choć bohater zostaje na farmie, aby być blisko ojca, czas spędza w stajni, zajmując się koniem. Jest zima, wszędzie leży śnieg, słychać powiewy wiatru, a chłopak stoi w otwartych drzwiach budynku i czyści zwierzę. Widać, 
że izoluje się od tego, co wydaje się mu niebezpieczne, obce, nieznane, czyli od perspektywy utraty ojca.

Hasłem przewodnim piątego odcinka serialu jest dojrzewanie, szóstego natomiast - śmierć (Walley-Beckett, Fox, 2017). To tutaj na początku Ania ratuje przed uduszeniem z powodu krupu siostrę Diany, Minnie May (Ryan Kiera Armstrong). To w tym epizodzie umiera ojciec Gilberta, a chłopak zostaje sam. Twórcy serialu już w poprzednim odcinku przygotowali nas, odbiorców, na taką ewentualność. W tej części zapowiedź śmierci Johna Blythe’a jest jeszcze wyraźniejsza. W około dziewiątej minucie filmu rozpoczyna się scena rozmowy ojca $\mathrm{z}$ synem, prowadzona w sypialni pierwszego $\mathrm{z}$ nich, bardzo schorowanego człowieka. Po prawej stronie łóżka, na ścianie, wisi lustro, w którym odbija się Gilbert. Na nocnym stoliku stoją jakieś butelki, moździerz, świeca, zdjęcie kobiety; leży też gruba książka. Gilbert siedzi przy łóżku i uczy się, nadrabiając szkolne zaległości. Nagle ojciec zaczyna opowiadać, co było (tak, używa tu czasu przeszłego!) najlepsze w jego chorobie - ponowna podróż na Zachód, pociągiem. „Świat jest wielki, synu. Pamiętaj o tym” - mówi John (Walley-Beckett, Fox, 2017) i brzmi to jak jego ostatnie przesłanie, mądrość, którą chce przekazać Gilbertowi. Chłopak na zmianę ukazywany jest w zbliżeniu bądź widzimy jego odbicie w lustrze, które nie odbija jego twarzy wyraźnie; jest ona zamglona, zamazana. Te ciekawe w swojej prostocie ujęcia mogą sugerować, że Gilbert jest zagubiony, znajduje się w momencie przejścia, nie wie, kim jest. A może jest niewyraźnym lub niewykształconym jeszcze odbiciem swojego ojca? Już niedługo przyjdzie mu zmierzyć się z tym pytaniem.

Pogrzeb ojca Gilberta odbywa się w pogodny zimowy dzień. Żałobników nie jest wielu, a przy świeżo wykopanym grobie stoi tak naprawdę tylko młody Blythe. Reszta utrzymuje dystans. Chłopak tłumi emocje, wygląda, jakby chciał powstrzymać łzy. Co ciekawe, więcej uczuć maluje się na twarzy Maryli (Geraldine James), która w młodości była związana z Johnem Blythe’m. Po tym, jak pastor odczytuje fragment Ewangelii, sąsiedzi rozchodzą się, a Gilbert zostaje sam, choć Ania dłuższą chwilę waha się, czy do niego nie podejść. Ostatecznie odchodzi z Cuthbertami. Nie jest to zawzięta, książkowa Ania, a współczująca koledze dziewczyna. Gilbert siada na ławce. Zaczyna padać śnieg. Chłopak łapie jeden płatek na dłoń. Kamera pokazuje nam bardzo dokładnie, jak śnieg ten topi się i spływa po ręce Gilberta. Wygląda jak łza, której w oczach osieroconego Blythe'a nie ma. Chłopak w dalszym ciągu tłumi emocje. Wkrótce da im dojść do głosu w bardzo nieoczekiwany sposób. Pełna dobrych chęci Ania oferuje Gilbertowi pomoc w przeżywaniu żałoby, pomoc, jak sama mówi, doświadczonej sieroty. Niestety, czyni to dość niefortunnie, stwierdzając, że ona nie znała swoich rodziców, a Gilbert zawsze będzie mógł wspominać ojca, więc 
w pewien sposób, w porównaniu do niej, ma szczęście. Chłopak odpowiada jej z wyrzutem: „Dlaczego chodzi o ciebie?” (Walley-Beckett, Fox, 2017) i odchodzi. Jego uczucia też można zranić, on również może być niemiły, zamiast być ciągle rycerskim, ale woli swój ból przeżywać w samotności.

Niedługo później okazuje się, że Gilbert nie tylko potrafi zachować się obcesowo w stosunku do dziewczyny. Tłumione uczucia dochodzą do głosu podczas rozmowy z Billym. Znany widzom ze skłonności do dręczenia Ani chłopak namawia Gilberta, by ten powrócił do szkoły, gdyż, jak mówi: „Ta brzydka sierota za bardzo się rządzi" (Walley-Beckett, Fox, 2017). Wymiana zdań na temat Ani kończy się groźbą pod adresem Billy’ego: „Jeśli będziesz ją nękać, pożałujesz tego" (Walley-Beckett, Fox, 2017). To jednak nie koniec konfrontacji - za chwilę Gilbert rzuci się na Andrewsa z pięściami. Wygra, a przynajmniej wygra z Billym. Ale czy wygra również ze swoimi emocjami? Jaki jest sens tej sceny? Pokazać przeżywanie żałoby przez Gilberta? Podkreślić, że zależy mu na Ani w szczególny sposób? Jeszcze bardziej oddzielić go od szkolnych kolegów, ich niedojrzałości? Być może odpowiedź na wszystkie te pytania jest twierdząca. Gilbert został sam, ma prawo do smutku, gniewu, do strachu. Co z farmą? Jak ma wyglądać jego przyszłość? Ojciec powiedział, że świat jest wielki. Co z tym zrobić? Przed sceną bójki widzimy Gilberta w sklepie. Zagaduje go tam Mateusz Cuthbert, oferując pomoc w uprawie roli. Chłopak odpowiada, że nigdy nie chciał być farmerem.

Krótką historię życia Gilberta widz serialu poznaje podczas rozmowy młodego Blythe'a z Marylą na cmentarzu, ta scena następuje zaraz po scenie bójki. Okazuje się, że chłopak jest ostatni z rodziny. W powieści była mowa o jakichś kuzynach z Nowego Brunszwiku, w książce też ojciec Gilberta nie umiera. Tutaj konsekwentnie scenarzystka buduje postać outsidera. To interesujący zabieg, bo w ten sposób więcej niż tylko ambicja i dobre wyniki w nauce łączą Blythe’a z Anią Shirley. Łączy ich to, że są inni niż ich rówieśnicy. Podczas gdy Ania - fizycznie, ale też w sposób symboliczny - zaczęła stawać się kobietą w dniu swojej pierwszej menstruacji, Gilbert zaczyna przechodzić z chłopięctwa w męskość w momencie, w którym musi wziąć na siebie odpowiedzialność za chorego ojca. A po jego śmierci - pełną odpowiedzialność za siebie. Dzięki konfrontacji z Gilbertem na pogrzebie oraz rozmowom z pogrążoną w żałobie ciotką Diany, Józefiną Barry (Deborah Grover), zmienia się też Ania. Jest w stanie wyjść poza swoje uczucia i w końcu zrozumieć kolegę. Jednakże gdy postanawia pojednać się z nim, okazuje się, iż w domu Blythe’ów nikogo nie ma (Walley-Beckett, Fox, 2017).

Twórcy serialu pozwolili nam mimo wszystko jeszcze w pierwszym sezonie obejrzeć scenę pojednania tych dwojga bohaterów. W ostatnim odcinku 
serii Ania i Gilbert spotykają się przypadkiem w mieście. O dziwo, od początku rozmawiają ze sobą normalnie, bez gniewu i pretensji, a nawet - po przyjacielsku (Walley-Beckett, Tapping, 2017). Okazuje się, że chłopak pracuje w dokach, nie chce teraz decydować o przyszłości farmy. „Najpierw zwiedzę kawałek świata. Jeśli powrócę do Avonlea, będzie to mój wybór, a nie obowiązek. Mój tata by tego chciał" (Walley-Beckett, Tapping, 2017). Ciekawe, że szykując się do podróży w poszukiwaniu siebie, realizuje plan ojca. Zanim zniknie na kilka miesięcy z rodzinnej wioski, pogodzi się z Anią. Podczas pożegnania widać, że między tymi bohaterami jest coś więcej niż szansa na dobrą przyjaźń. Oboje są jednak jeszcze za młodzi, by zrozumieć, co się między nimi dzieje.

\section{Zakończenie. Kim jest Gilbert Blythe?}

Gilbert książkowy czy serialowy? W przypadku adaptacji tak znanej - i lubianej - powieści każda ingerencja w fabułę czy charakter postaci może wywołać kontrowersje. Serial Ania, nie Anna wywołał ich całkiem sporo i chyba należałoby go oceniać nie jako adaptację, a jako obraz inspirowany książką Montgomery i, nie unikając koniecznych porównań, oceniać oba dzieła oddzielnie, jako autonomiczne teksty kultury.

Książkowy Gilbert Blythe stanowi tło dla głównej bohaterki. Wiemy o nim w zasadzie niewiele, bo przecież nie można oceniać jego charakteru przez pryzmat tego, co myśli o nim lub co wyobraża sobie na jego temat Anna Shirley, wyraźnie do chłopca uprzedzona. Podczas uważnej lektury można odnieść wrażenie, że Gilbert mógłby w zasadzie nie pojawiać się w utworze osobiście, być jak bohater powieści o dziewczętach uczących się na pensji, które jedynie myślą lub rozmawiają - i to na marginesie szkolnych perypetii - o chłopcach. Chłopcach, którzy potem stają się ich narzeczonymi bądź mężami. Taki schemat realizują np. takie oddalone od siebie w czasie powieści jak wspomniana na początku artykułu polska Szkoła narzeczonych Marii Krüger (1945), niemiecka Przekora Emmy von Rhoden (1883/1993) czy Tajemniczy opiekun Jean Webster (1912/1993). Wiedząc o Gilbercie jedynie to, że jest bardzo dobrym, uzdolnionym uczniem, a także młodym mężczyzną zdolnym do poświęcenia swojej posady dla koleżanki, trudno przypisać go do konkretnego wzoru męskości/chłopięcości. Należałoby przyjrzeć się tej książkowej postaci z perspektywy studiów nad męskością, wciąż na gruncie polskim raczkującej gałęzi humanistyki. Tutaj warto byłoby postawić pytanie, jak ma się postać młodego Blythe’a do podobnych mu książkowych bohaterów oraz obowiązującego pod koniec XIX wieku wzoru czy obowiązujących wzorów męskości. Angela 
Carter (1987/2000) w swojej interpretacji Kopciuszka napisała, że w „tym dramacie pomiędzy dwiema żeńskimi rodzinami, pozostającymi ze sobą w konflikcie z powodu rywalizacji o mężczyzn [...], mężczyźni wydają się zaledwie biernymi ofiarami kobiecych pragnień, ale ich znaczenie jest decydujące, bo ma (»bogaty człowiek«, »syn królewski«) charakter ekonomiczny” (s. 350). Postać Gilberta co prawda nie ma charakteru ekonomicznego, ale w opowieści o Ani pełni podobną funkcję - pozwala bohaterce zaistnieć, wyróżnić się na forum klasy szkolnej, a następnie to on decyduje o tym, że dziewczyna zostaje w Avonlea przy Maryli. Powieściowy Gilbert kolejny raz wchodzi w rolę rycerza ratującego damę $\mathrm{z}$ opresji.

Serialowy Gilbert Blythe A.D. 2017 jest rycerski ${ }^{12}$, podoba się dziewczętom, zdaniem pana Philipsa jest najlepszy w klasie. Choroba ojca i jego śmierć sprawiają jednak, że chłopak dojrzewa szybciej niż szkolni koledzy, szybciej też musi wziąć za siebie odpowiedzialność. Jego podejście do dziewcząt diametralnie różni się od reprezentowanego przez rówieśników. Nie dokucza Ani i jej przyjaciółkom, nie poniża ich, nie lekceważy. Wydaje się, że jest „ponad to”, a jego postać została skonstruowana tak, by stać się przeciwwagą - mimo tego, co zrobił w klasie Ani Shirley - dla stereotypowego chłopca: łobuza ciągnącego dziewczęta za warkocze, któremu pozwala się na używanie przemocy w różnych jej przejawach w myśl zasady boys will be boys (polska wersja brzmiałaby: „Bo chłopcy już tacy są”).

Ryszard Koziołek (2011) napisał o innym bohaterze klasyki dla młodego czytelnika, Stasiu Tarkowskim, że „zgodnie z poglądami pisarza i trendami epoki [...] reprodukuje wzorzec angielskiego dżentelmena ze szlachetną domieszką polskiej tradycji rycerskiej, a zarazem reprezentuje już nowy typ dziejowego bohatera [...] - wynalazcę i konstruktora" (s. 124). Pytanie, które w tym miejscu można by zadać, dotyczy tego, jakie wzorce reprodukuje i reprezentuje serialowy Gilbert Blythe. Czy jest to ideał dorastającego młodzieńca z epoki późnowiktoriańskiej, czy raczej wrażliwy i dojrzały chłopiec skrojony na miarę ideału dorastającego mężczyzny z początku XXI wieku? Mogę wysnuć wstępny wniosek, że postaci zarówno Ani, jak i Gilberta zostały uwspółcześnione, napisane na nowo. Zauważmy, że protagonistka różni się od dziewcząt z klasy wyobraźnią, nadmierną ekspresją uczuć, traumą z dzieciństwa, ambicjami. Gilbert różni się zaś od chłopców powagą, dojrzałością oraz, podobnie jak Ania, ambicjami naukowymi. W ten sposób po dwóch stronach klasy w szkółce w Avonlea twórcy serialu ukazują dwójkę samotników, oddzielonych

12 Przypomnijmy, że tak określa go jedna z bohaterek. 
od wspólnoty, choć we wspólnocie. Bohaterowie nie pasują do małej wioski na Wyspie Księcia Edwarda, ale dzięki temu, że są outsiderami, pasują do siebie. Ponadto, dzięki nowoczesnej kreacji serialowych postaci, widz z XXI wieku może się z nimi identyfikować bardziej niż z literackimi pierwowzorami.

Po pierwszym sezonie Anne with an E nie znamy jeszcze pełnej odpowiedzi na pytanie, kim jest Gilbert Blythe. Postać rozwija się w sezonie drugim w dość interesujących okolicznościach, których autorka literackiego pierwowzoru na pewno by dla tego bohatera nie zaprojektowała. Za to, co ciekawe, serialowy Gilbert wzmacnia w sobie cechy, w które wyposażony został jego powieściowy pierwowzór: rozwagę, empatię, odwagę, wrażliwość na cudzą krzywdę.

\section{Bibliografia}

Åhmansson, G. (1991). A life and its mirrors: A feminist reading of L. M. Montgomery's fiction. Volume 1: An introduction to Lucy Maud Montgomery, Anne Shirley. Uppsala: Uppsala University.

Austen, J. (2016). Duma i uprzedzenie (M. Moltzan-Małkowska, tłum.). Warszawa: Prószyński i S-ka. (wyd. oryg. 1813).

Carter, A. (2000). Popielucha, czyli duch matki. W: Czarna Wenus (A. Ambros, tłum., s. 349-362). Warszawa: Czytelnik. (wyd. oryg. 1987).

Gammel, I., Epperly, E. (red.). (1999). L. M. Montgomery and Canadian culture. Toronto, Bufallo, NY, London: University of Toronto Press.

Gammel, I., Lefebvre, B. (red.). (2010). Anne's world: A new century of Anne of Green Gables. Toronto, Bufallo, NY, London: University of Toronto Press.

Gralewicz-Wolny, I. (2013). Ania z Zielonego Wzgórza - powieść dla „niegrzecznych” dziewcząt. W: B. Niesporek-Szamburska, M. Wójcik-Dudek (red.), Nowe opisanie świata. Literatura i sztuka dla dzieci i młodzieży w kręgach oddziaływań (s. 89-98). Katowice: Wydawnictwo UŚ.

Hoły, J. (2011). Wydawnicze dzieje cyklu Ani z Zielonego Wzgórza Lucy Maud Montgomery na ziemiach polskich. Nieopublikowana praca magisterska, Wydział Zarządzania i Komunikacji Społecznej, Uniwersytet Jagielloński, Kraków. Pobrane z: https://jbc.bj.uj.edu.pl/dlibra/publication/191182/edition/180332/content? ref=desc.

Kęczkowska, B. (2003, 1 sierpnia). Rozmowa z Agnieszką Kuc, tłumaczka Ani z Zielonego Wzgórza. Wyborcza.pl. Warszawa. Pobrane z: http://warszawa.wyborcza.pl/ warszawa/1,34861,1604522.html.

Kędziorzyna, M. (1946). Odstraszające pozory. Dziś i jutro, 16(22), 12.

Koziołek, R. (2011). Męskość Stasia. W: Znakowanie trawy albo praktyki filologii (s. 123-139). Katowice: Wydawnictwo UŚ. 
Krüger, M. (1945). Szkoła narzeczonych. Warszawa: Wydawnictwo E. Kuthana.

Lindgren, A. (2015). Pippi Pończoszanka (I. Szuch-Wyszomirska, tłum.). Warszawa: Nasza Księgarnia. (wyd. oryg. 1945).

Malicka, J. (2008). Ania prababka Pippi. Guliwer, 2(84), 17-23.

Ledwell, J., Mitchell, J. (red.). (2013). Anne around the world: L. M. Montgomery and her classic. Montreal, London: Ithaca.

Rient, R., Seklecka, E., Walczak, M., Walicka, A., Zierkiewicz, E. (red.). (2014). Męskość $i$ kobiecość w lekturach szkolnych. Analiza treści lektur w szkole podstawowej i gimnazjum z perspektywy płci. Raport $z$ badań. Wrocław: Fundacja Punkt Widzenia.

McDougall, I., Sullivan, K. (prod.). (1985). Anne of Green Gables [Ania z Zielonego Wzgórza] [serial telewizyjny]. Ottawa: CBC.

Montgomery, L. M. (1911). Ania z Zielonego Wzgórza (R. Bernsteinowa, tłum.). Warszawa: Wydawnictwo M. Arcta. (wyd. oryg. 1908).

Montgomery, L. M. (2003). Ania z Zielonego Wzgórza (A. Kuc, tłum.). Kraków: Wydawnictwo Literackie. (wyd. oryg. 1908).

Montgomery, L. M. (2014). Ania z Zielonego Wzgórza (wyd. 2. popr., P. Beręsewicz, tłum.). Kraków: Skrzat. (wyd. oryg. 1908).

Oczko, P. (2013). Anna z domu o zielonym dachu. O cyklu powieściowym Lucy Maud Montgomery. Teksty Drugie, 5, 42-61.

Oczko, P., Nastulczyk, T., Powieśnik, D. (2018). Na szwedzkim tropie Ani z Zielonego Wzgórza. O przekładzie Rozalii Bernsteinowej. Ruch Literacki, 3(348), 261-280. https://doi.org/10.24425/122705.

Tennyson, A. (1902). Lancelot and Elaine. W: M. K. Bellew (red.), Tales from Tennyson (s. 104-119). New York, NY, Boston, MA: H. M. Calwell. (wyd. oryg. 1859).

Von Rhoden, E. (1993). Przekora (Z. Zajączkowska, tłum.). Wrocław: Siedmioróg. (wyd. oryg. 1883).

Walley-Beckett, M. (prod.). (2017- ). Anne with an E [Ania, nie Anna] [serial telewizyjny]. Ottawa, Los Gatos, CA: CBC, Netflix.

Walley-Beckett, M. (scen.), Caro, N. (reż). (2017). Your will shall decide your destiny [Niech twoja wola decyduje o twoim losie] [odcinek serialu telewizyjnego]. W: M. Walley-Beckett (prod.), Anne with an E [Ania, nie Anna]. Ottawa, Los Gatos, CA: CBC, Netflix.

Walley-Beckett, M. (scen.), Evans, D. (reż). (2017). An inward treasure is born [Skarb w głębi duszy] [odcinek serialu telewizyjnego]. W: M. Walley-Beckett (prod.), Anne with an $E$ [Ania, nie Anna]. Ottawa, Los Gatos, CA: CBC, Netflix.

Walley-Beckett, M. (scen.), Fox, P. (reż). (2017). Remorse is the poison of life [Wyrzuty sumienia to trucizna życia] [odcinek serialu telewizyjnego]. W: M. Walley-Beckett (prod.), Anne with an E [Ania, nie Anna]. Ottawa, Los Gatos, CA: CBC, Netflix.

Walley-Beckett, M. (scen.), Goldbacher, S. (reż.). (2017). But what is so headstrong as youth [Cóż jest bardziej uparte od młodości] [odcinek serialu telewizyjnego]. 
W: M. Walley-Beckett (prod.), Anne with an E [Ania, nie Anna]. Ottawa, Los Gatos, CA: CBC, Netflix.

Walley-Beckett, M. (scen.), Rozema, P. (reż). (2017). Tightly knotted to a similar string [Nierozerwalny węzeł przyjaźni] [odcinek serialu telewizyjnego]. W: M. Walley-Beckett (prod.), Anne with an E [Ania, nie Anna]. Ottawa, Los Gatos, CA: CBC, Netflix.

Walley-Beckett, M. (scen.), Tapping, A. (reż). (2017). Wherever you are is my home [Gdziekolwiek jesteś, tam jest mój dom] [odcinek serialu telewizyjnego]. W: M. Walley-Beckett (prod.), Anne with an E [Ania, nie Anna]. Ottawa, Los Gatos, CA: CBC, Netflix.

Webster, J. (1993). Tajemniczy opiekun (R. Centerszwerowa, tłum.). Warszawa: Nasza Księgarnia. (wyd. oryg. 1912).

Whitman, W. (1856). Poem of the road. W: Leaves of grass (s. 223-239). Brooklyn, NY: Fowler and Wells.

Wieczorkiewicz, A. (2017). „Złoty wiek”: oddalenia, przekroje. 80 lat anglosaskiej klasyki dla dzieci i 150 lat jej przekładów na język polski w trzech makroperspektywach. Forum Poetyki, 10, 66-91. 